\title{
»Do not touch it!« Today's Children’s Visual Competencies in Comparison with the Pre-Digital Era in Light of their Art Educational Environment
}

Gabriella PATAKY ${ }^{1}$

$\approx$ The task of twenty-first century art education is to contribute to the blossoming of the child's personality. In this article, I approach this challenge from two principal directions, both of which provide a window onto unfamiliar terrain. This project sought to answer the following research questions: How do plastic, spatial (3D) creative capacities develop, and how do they compare with the kindergarten's accustomed advancement of picture-creating, planar (2D) capabilities? How do kindergartners' skills as measured in the 1970s compare with those of kindergartners today? A follow-on project examined children's skills in the context of built environment education, asking the questions: Where, and with whom, do children find the best conditions for creation and arts education? What kinds of environments are most favourable? The results showed a clear deterioration of children's drawing development from 1974 until today, as well as from drawings in both studies to modelling today. However, a more promising discovery was that depictions of movement appear much sooner in the case of plastic arts works than in drawings. This opens the way to an orientation that in our increasingly urbanised world, can help our children grow into adults who responsibly shape our environment, sensitive to their own age, as self-possessed problem solvers, employing the toolkit of education through art. The study is based on ongoing, long-term research of the $3612+$ Visual Skills Lab group, employing both qualitative and quantitative methods to evaluate the artistic proficiencies of nearly a thousand children, mostly aged $3-7$, in dozens of kindergartens in Hungary, through hands-on exercises as well as surveys of teachers, parents and other interested parties.

Keywords: art education environment, built environment education, design thinking, early childhood art education, visual competencies development

1 Faculty of Primary and Pre-School Education, Eötvös Loránd University, Hungary; patakyella@gmail.com. 


\section{»Ne dotikajte se!« Današnje vizualne kompetence otrok $\mathrm{v}$ primerjavi s preddigitalno dobo v luči njihovega likovnovzgojnega okolja}

Gabriella Pataky

$\propto$ Naloga likovne vzgoje 21. stoletja je prispevati k razcvetu otrokove osebnosti. $\mathrm{V}$ tem prispevku se tega izziva lotevamo iz dveh glavnih smeri, ki obe ponujata pogled na nepoznan teren. Ta projekt je poskušal odgovoriti na naslednji raziskovalni vprašanji: kako se razvijajo plastične, prostorske $(3 \mathrm{D})$ ustvarjalne sposobnosti v primerjavi $\mathrm{z}$ običajnim napredovanjem slikovnih, dvodimenzionalnih (2D) zmožnosti otrok v vrtcu; kako se spretnosti otrok, vključenih v okolje vrtcev, merjene v 7o. letih, primerjajo s spretnostmi otrok $\mathrm{v}$ vrtcih danes. Nadaljnji projekt je preučeval otrokove spretnosti $\mathrm{v}$ okviru vsebin prostorskega oblikovanja $\mathrm{z}$ naslednjimi vprašanji: $v$ kakšnem okolju in s kom imajo otroci najboljše pogoje za ustvarjanje in likovno učenje; katera okolja so najprimernejša. Izsledki so pokazali očitno poslabšanje razvoja otroške risbe od leta 1974 do danes, in sicer v obeh študijah s področja risanja, pa tudi upad spodobnosti na področju plastičnega oblikovanja. Študija je pokazala tudi obetavne ugotovitve, da se upodobitve gibanja v otroških likovnih delih pojavijo prej na področju plastičnega oblikovanja kot na področju risanja. Ta spoznanja odpirajo pot smernic, ki lahko v našem vse bolj urbaniziranem svetu pomagajo otrokom, da odrastejo v osebe, ki z odgovornostjo oblikujejo naše okolje, občutljivo glede na svojo starost, kot samostojni reševalci problemov z uporabo orodij učenja skozi likovno vzgojo. Študija temelji na dolgoročni raziskavi skupine $3612+$ Visual Skills Lab, ki uporablja kvalitativne in kvantitativne metode za oceno likovne usposobljenosti skoraj tisoč otrok, večinoma starih od 3 do 7 let, $\mathrm{v}$ več deset vrtcih na Madžarskem, s praktičnimi vajami ter $\mathrm{z}$ anketami med učitelji, starši in drugimi zainteresiranimi stranmi.

Ključne besede: likovnoizobraževalno okolje, vzgoja o prostorskem oblikovanju, proces razmišljanja o oblikovanju, likovna vzgoja v zgodnjem otroštvu, razvoj vizualnih kompetenc 


\section{Introduction}

»Don't touch!« This brutal intervention into the freedom of personal expression of young children is often heard. Has anyone actually counted the number of times a child hears this expression before s/he begins her/his schooling? Even without statistics, it is foreseeable that without independent activity and her/his own experience, the development of the child's personality will be hindered. We have to establish a secure and inspiring creative environment necessary for the attainment of visual education. Learning exercises should be created with an understanding of the characteristics of the particular age group and of the particular children or pupil groups at educational institutions. In practice, however, we see that instead of consciously planned assignments geared towards developing the child's competencies, what is taking place are activities convenient for interested adults (teachers and parents), often spread through social media.

A thorough approach to visual education, grounded in research, is even more important in the age of the democracy of the internet. Abetted by social media, the servile copying of the commonplace increasingly replaces the creation of objectives selected towards the conscious development of competencies. For the most part, this phenomenon does not even consist of the duplication of teaching plans, but images of the products of instruction. If these are pleasing, the necessary materials and tools are obtained, and in subsequent lessons an attempt is made to produce the same result, or something similar, with the pupils. Especially in the case of the youngest pupils, solutions arise through imitation, a kind of dictation on the basis of external images. The problem with this is not only that the children's own internal images and imagination go unused, or that the pedagogical utilisation of the creative process is much less effective, but also that those competencies and abilities that would be necessary for their development are purposely not mobilised. This kind of democracy, while spreading a false feeling of professional security, deprives the community of prospective development based on shared knowledge.

The present paper pursues one of the new objectives of the International Society for Education Through Art (InSEA): offering support to early childhood educators to get to know the most up-to-date trends in visual education (»Education through Art «). ${ }^{2}$ Kindergarten, preschool, elementary/primary school, generalist and in-service teachers all teach art passionately in their day-to-day work, but this practice is not represented enough in art teacher associations. They need more help to develop themselves, especially in relation to new

2 See https://www.insea.org/insea/about-insea; https://www.insea.org/Gabriella-Pataky. 
concepts of early childhood education and primary schooling in Europe, which propose a complex, transdisciplinary, competence-based curriculum.

UNESCO defines early childhood care and education as follows:

Early childhood, defined as the period from birth to eight years old, is a time of remarkable growth with brain development at its peak. During this stage, children are highly influenced by the environment and the people that surround them. Early childhood care and education (ECCE) is more than preparation for primary school. It aims at the holistic development of a child's social, emotional, cognitive and physical needs in order to build a solid and broad foundation for lifelong learning and wellbeing. ECCE has the possibility to nurture caring, capable and responsible future citizens. ${ }^{3}$

During this stage, children are highly influenced by the environment and the people that surround them. The younger the children, the more exposed they are; this is a time when their guardian's responsibility is most important, as children are more willing to do what they are told. Despite a child's upbringing being considered one of the most significant future investments, little prestige is given to it.

The speed with which our visual world changes means that the visual development of children in their equally swiftly evolving culture requires special awareness. Previously published models of scientific visual research skills and reinterpretations of pictorial clichés (Mitchell, 1994) are only partially helpful to teachers using traditional methods who wish to cope with the particular challenges of today (Bodóczky, 2003). It is necessary to take seriously the visual turn, long argued as fundamental by Mitchell (2004).

Statistical research on the development of plastic art skills, with the participation of a large number of children, has only been carried out by one researcher, Claire Golomb (1974). For the current research project, I took Golomb's model as my base point. My intention was to compare the drawings as well as the sculptures of that time with those of today. To make the comparison, I have chosen a research project on children's drawings from the same era, Ákos Paál's (1974) quantitative research, performed on a large sample. I endeavoured to answer the question: Have children's drawings changed along with the changes in the world in the past 40 years?

According to my previous research findings concerning diagnostic methods (Pataky, 2012), two-dimensional imaging exercises are disproportionately

3 See https://en.unesco.org/themes/early-childhood-care-and-education. I focus here particularly on the age of 3-7 years, mainly on preschool but also on primary school education. I use the term »kindergarten « for the years from $3-7$, recognising that in some countries kindergarten ages may differ. 
emphasised in visual education, both in infant nurseries and kindergartens. In that research, an online questionnaire for focus groups, parents, kindergarten teachers and primary school teachers revealed that exercises in the area of $2 \mathrm{D}$ visual expression dominated, while object-making $(3 \mathrm{D})$ exercises and the time spent on them, as well as the quality of work, fell far behind, despite the recommendations of the National Curriculum 2010 (and 2013) education management documents.

The present article proposes a new research direction in early childhood education, centred on plastic (three-dimensional) visual education. In the twenty-first century, it is evident that children are losing natural skills, and that results-oriented arts education is failing to meet them where they live and grow, in terms that relate to their own experience (Inspectorate of Education / Ministry of Culture and Science, 2017). Rather than forcing a certain orientation, it is crucial to teach children how to get to know and to express their own world, a world that is undergoing constant shaping and design. Accepting them as autonomous beings, giving them more and more responsibility, sets them on a path to becoming aware citizens. All of this can be fostered through a conscious visual education/arts teaching practice, focused on the constructed environment as children experience it.

This tendency is largely unresearched, with some scattered exceptions, most notably Constance Kirchner's research (2015). ${ }^{4}$ Built environmental education has some presence, especially in Germany, and it has been introduced into Hungary by way of the research project Common European Framework for Reference in Visual Literacy (CEFR_VL), operating through our group, the Tudományegyetem Tanító- és Óvóképző Kar (Eötvös Loránd University Faculty of Primary and Preschool Education) (ELTE TÓK) »3612+ Visual Skills Lab«. I will survey the research we have carried out in this area, with reference to the (minimal) precursors to it, and conclude with the prospects and possibilities it projects, as well as the benefits for early childhood education and its subjects, the children.

The project sought to answer the following research questions: How do plastic, spatial $(3 \mathrm{D})$ creative capacities develop, and how do they compare with the kindergarten's accustomed advancement of picture-creating, planar $(2 \mathrm{D})$ capabilities? How do kindergartners' skills as measured in the 1970s compare with those of kindergartners today? A follow-on project examined children's skills in the context of built environment education, asking the questions:

4 Another example is the report "Level Artistic Orientation 2015-2016", similarly related to art education, in which education inspection experts in the Netherlands expressed their concerns (Inspectorate of Education / Ministry of Culture and Science, 2017). 
Where, and with whom, do children find the best conditions for creation and arts education? What kinds of environments are most favourable?

Another aspect of the research examined the value of the sense of touch in artistic perception: To what extent do children actually also »see« with their hands? Valuable research exists on the sensory development of the tactile receptors on the palm of the hands. The specialised innervation of the fingertips allows for very fine and complex movements and precision of sensation. These are not congenital skills, but can be learnt and developed (Katona, 2001), as can spatial perception, by the final year of kindergarten (Szőkéné, 2010). The nerve endings under the skin surface of the palm and fingers can be adapted quickly, which means that so-called »Meissner bodies« are activated when our skin touches something. However, as the years go by (from the age of about 10), the number of tactile receptors in the fingertips gradually decreases (Lakatos, 2007). This indicates a contradiction in a sentence we often hear from adults in reference to young children: »Don't touch this or that!«

Our primary findings were first presented in 2018 in Budapest, and then at the Helsinki session of the InSEA Conference (Tóth \& Pataky, 2019) ${ }^{5}$. However, aside from conference presentations and a brief summary of the second part of the research in a conference volume, our results have not been published in English.

Parallel to the development of the CEFR_VL prototype (Pataky, 2016), our study of kindergartners (Pataky, 2017a) has been a test of the practical applicability of the CEFR_VL model. Our results clearly indicate where intervention is most urgent: while visual communication and visual learning today play an ever more decisive role in a world undergoing constant change, today's children show a deterioration in the development of their visual abilities compared to the last forty years.

What kind of development is necessary during the first years of institutional education in order to optimally expand children's visual knowledge? I would like to take our $3612+$ Visual Skills Lab group's research results as a starting point and use diverse interactive methods to seek answers to the particular questions of visual education for young children, while surveying possibilities contained in the toolbox offered by the CEFR_VL model (Kárpáti \& Pataky, 2016; Wagner, \& Schönau, 2016) that can raise awareness of the planning of pedagogical processes for early childhood educators (kindergarten and primary school teachers) who (also) teach visual arts.

5 Built environment education was first introduced in Hungary in early childhood education in our ELTE TÓK department, making us pioneers. With the first book related to early childhood pedagogy published in Budapest (Guba et al., 2017), endorsed by InSEA, we explore this new, transdisciplinary but less travelled field based on the CEFR_VL, linked strongly to visual education. 


\section{Competency measurement as a means to improve peda- gogical action}

Like other schoolwork, visual education, education through art, is normally organised around tasks. In early childhood, it is a question of a balance between process- and product-oriented exercises or experiments, as a very special and characteristic form of learning in this age group. Even at this age, competency-based tasks allow for complex development of the individual. Personal development may be joined with the development of visual competencies. Knowing their pupils, teachers may then work towards an adaptive, optimal developmental direction for them.

The CEFR_VL model's skills list (Kárpáti \& Pataky, 2016; Wagner \& Schönau, 2016) offers a collection of competency elements that serves as a basis for pedagogical planning (of lessons, projects, weekly topics, etc.). Teachers can create tasks taking into account personal abilities, the principles of developmental psychology, and the recommendations of educational regulatory documents.

In teaching, the promotion of visual literacy competencies is predominantly induced and realised by means of tasks, especially tasks that promote artistic creativity. Such tasks should be determined by a complex and interdisciplinary approach. These tasks must be developed, yet the question arises how learning processes can purposefully be accompanied by formative evaluation ${ }^{6}$ and a summative assessment of learning results (Bodóczky, 2000). Assessment - in the sense of testing the success of learning through examination tasks - plays a very important role for diagnostic purposes: At what stage is the learner during or after the learning process? What are her or his strengths? Which problems and deficits become apparent? Which (sub-)competencies can be discerned?

This is not, however, only important for the diagnosis of the learners' progress and thus for the improvement of learning, but also for the improvement of teaching. A further purpose of assessment in the context of teaching is the optimisation of pedagogic action. Reulecke and Rollett (1976, p. 177) write that »diagnostics in decisive situations in school serves to gain information for the optimisation of pedagogic action«. They utilised the definition formulated by the Bund-Länder-Kommission from 1974, which contains all of the essential aspects a teacher needs for adequate pedagogic action: »The term pedagogic diagnostics refers to measures to shed light on specific problems, to assess the success of teaching and learning, and to assess the individual's educational potential in the pedagogic field, especially such measures that help to choose a school career, a training course, a vocational training or further education«

6 A continuous dialogue between learners and teachers is crucial for learning (OECD, 2005). 
(quoted in Reulecke \& Rollett, 1976, p. 177). The PISA Consortium also relates assessment/diagnostics to learning and teaching in this way: »A central precondition for an ideal promotion [of learners] is the teachers' sufficient diagnostic competence, i.e. the ability to correctly assess the learners' level of knowledge as well as their processing and understanding of input. Diagnostics in decisive situations in school serves to gain information for the optimisation of pedagogic action« (Deutsches PISA Konsortium, 2001, p. 132). In this sense, pedagogic diagnostics comprises all measures that contribute to the improvement of learning and teaching through observation, here especially the assessment of teaching-learning success. Thus, teachers must also be diagnosticians, with the capacity to conceive the preconditions, processes, results and environments of learning. Using our ongoing diagnostic research related to early childhood education as an example, I will show how this can be put into practice.

\section{Method}

The research presented here focused squarely on the creation of timely models of contemporary children's creation and on the varied development of visual capacities, which play a key role in children's personality growth. The objective was to carefully study the minimal and optimal levels of development in the 3-7-year-old age group, in order to determine the best conditions for arts education. I emphasised three-dimensional $(3 \mathrm{D})$ evaluation exercises so as to offset the dominance of two-dimensional (2D) image-making exercises in art education. The project focused on establishing a structure for analysing visual skills, and on aspects of the development of these skills. With support from InSEA Europe, the research was carried out as part of the larger CEFR_VL project, established by the European Network for Visual Learning (ENViL) research group. ${ }^{7}$ Within the CEFR_VL structure of competencies, a set of measurements enabled evaluation of the three-dimensional visual skill levels of plastic art and construction work by children aged 3 to 7 , and focused on drafting an appropriate system of tools to assess skills applied in everyday life, such as creative problem solving, material and tool use, space perception, planning, sign creation and interpretation, and experimentation.

In the main research project, I carried out experimental exercises with 815 children aged 3 to 7 in 28 kindergartens in Hungary. Most of the kindergartens involved are connected to ELTE TÓK kindergarten teacher training, which means that the result of this research is not only put into effect at participant kindergartens, but also directly in kindergarten teacher training. It makes

7 Nr.: 538568-LLP-1-2013-1-DE Comenius CMP. (European Research Fund project identifier - 2014-17). 
direct and effective use of the CEFR_VL competency model, and thus finds approval with direct users (practising and beginning kindergarten teachers).

The measuring tool system for the plastic $(3 \mathrm{D})$ skill research, developed specifically for this project, was organised into four packages of tests and other investigations, divided into equal parts of the 2014/2015 school year.

The first package of plastic exercises for the measurement of visual skills included free experimentation with the material, making imaginative figures and free forms. The resulting creations were analysed on the basis of 13 elements, including the children's choices of materials, perspective and method; the level of differentiation and detail in the works produced; their sense of proportion; recognisability as a human figure; and portrayal (or lack thereof) of a sense of motion.

Part two focused on games based on the coordination of optical and tactile senses. In addition, I recorded precise measurements about the power of the children's hands with a particular instrument (a circus "strongman «, which the children were encouraged to emulate, was the framework of the game). The collected data here, from 2015/16, will have an important role in a future longitudinal study. I obtained information about the coordination of the optical and tactile senses of the children with the help of a tool I developed and designed, nicknamed the "peeking basket «. The children were asked to identify and select 11 different objects (pine cone, plush bunny, chestnut, etc.) by means of touching them while the objects were invisible to them, hidden in a box.

Part 3 studied the sense of proportion and scale. I created a simple puzzle-like game as a measurement tool to assess the awareness of scale (simple egg shapes of differing sizes to which could be attributed family relationships, i.e., a large egg equating to a father, a small egg to a baby). As an additional test, I applied a drawing to compare the drawn figure and the modelled figure. I asked the children to draw themselves with the person who had brought them to kindergarten that day.

In part 4 , the children were asked to shape a human figure from clay. This part of the investigation was the most influential. We then evaluated the exercise results in the light of the kindergarten background variables. These variables were mapped (charted) by analysing the data from two surveys:

1. the children's development survey, ${ }^{8}$ and

8 Questionnaire on background variables concerning the development of each child.

We asked:

- the exact age of each child;

- the duration of involvement in institutional education;

- the gender of each child for gender-specific questions/findings;

- the teacher's evaluation of each child's performance in these exercises in kindergarten;

- a statement of special needs;

- which hand is dominant. 
2. the institutional environmental facilities survey. ${ }^{9}$

The credibility of the study is based in the joint employment of qualitative and quantitative research methods. In the first, diagnostic phase, qualitative elements predominated: the field work and the processing and analysis of the data gained from the children's work and resolution of tasks were carried out with statistical methods.

In the case of the kindergarten cohort, the observation of process was a key aspect, since the creations declared finished were only evaluable by means of the creator's narrative. For this reason, the recording of the children's descriptions of their work was especially important. To this end, after the procurement of the appropriate parental permissions, detailed photographic documentation of the phases of creation was carried out, while video recordings were made of the creators' self-reflections. The process diagnostics of distinct series were produced for the whole sample, while the video recordings were made only of certain children, utilising the insights of qualitative research methods (Bodor, 2013).

Document analysis was used to examine the educational prescriptions relevant to our topic: the national basic programme for kindergarten education; the national school curriculum, relevant to the transition period from kindergarten to school; the curriculum framework for visual education; and the visual education methodological programme principles for preschool and primary school teacher training in Hungary. Prior to the diagnostic examination, we considered it particularly important to register a situation report on the current regulatory system; the "weightlessness « of the above documents, which do not deserve a systematic evaluation, are characteristic of the kindergarten environment.

In the following $(2015 / 16)$ school year, I carried out a follow-on study aimed at imagining optimal art educational spaces. I utilised iconographical analysis to evaluate 714 drawings by Hungarian children aged 5-10 years, expressing how they imagine the spaces they would be happiest to create in.

In the aforementioned ongoing investigation (Pataky \& Rekvényi, 2016), one of the three main research directions was asking the children to draw where they like to create. The images in this research model are specially coded forms

9 Questionnaire on the background variables of the institutional environment facilities.

This questionnaire asked:

- the qualifications of the teachers;

- the creative circumstances plus the material and tool supply;

- the basic data for kindergartens and kindergarten teachers.

The questionnaire ended with a question directing a short essay, from which we aim to discover the reasons why these invaluable dimensional exercises are ignored or not more widely used. 
of messages. This indirect iconographical method is useful in this case as well as others, because it does not idealise reality, but rather faces the truth. In this ongoing investigation, we are analysing these drawings in many aspects.

\section{Figure 1}

Two aspects of the evaluation criteria: $2 \mathrm{D}$ v. $3 \mathrm{D}$ ( $1^{\text {st }}$ element) and recognisability of human form ( $13^{\text {th }}$ element), from least (on the left) to most recognisable (on the right)

DRAWING or SCULPTURE?

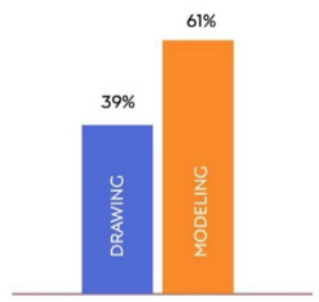

1st element

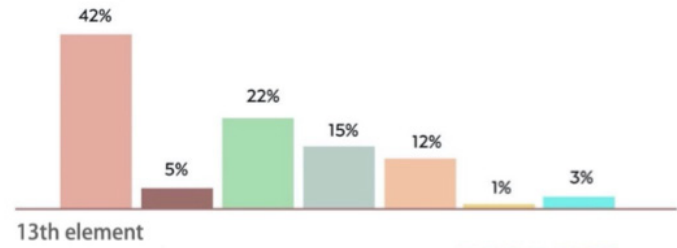

0123456

\section{Results}

Part 1 of the research showed both the potential and weakness of plastic creation skills. When the children could choose their materials and subjects freely, most of them (197 of 323, or 61\%) created a $3 \mathrm{D}$ form instead of a drawing (Element 1 of the evaluation criteria; see Fig. 1). However, a detailed examination of the recognisability of the human form (Element 13) in the sculptures created showed that the largest proportion, $42 \%$, were classifiable as "amorphous «, not at all resembling a human figure; only $3 \%$ made a sculpture that was perfectly recognisable from all angles. 


\section{Figure 2}

Materials used in various kindergartens of the sample (the top line represents all kindergartens)

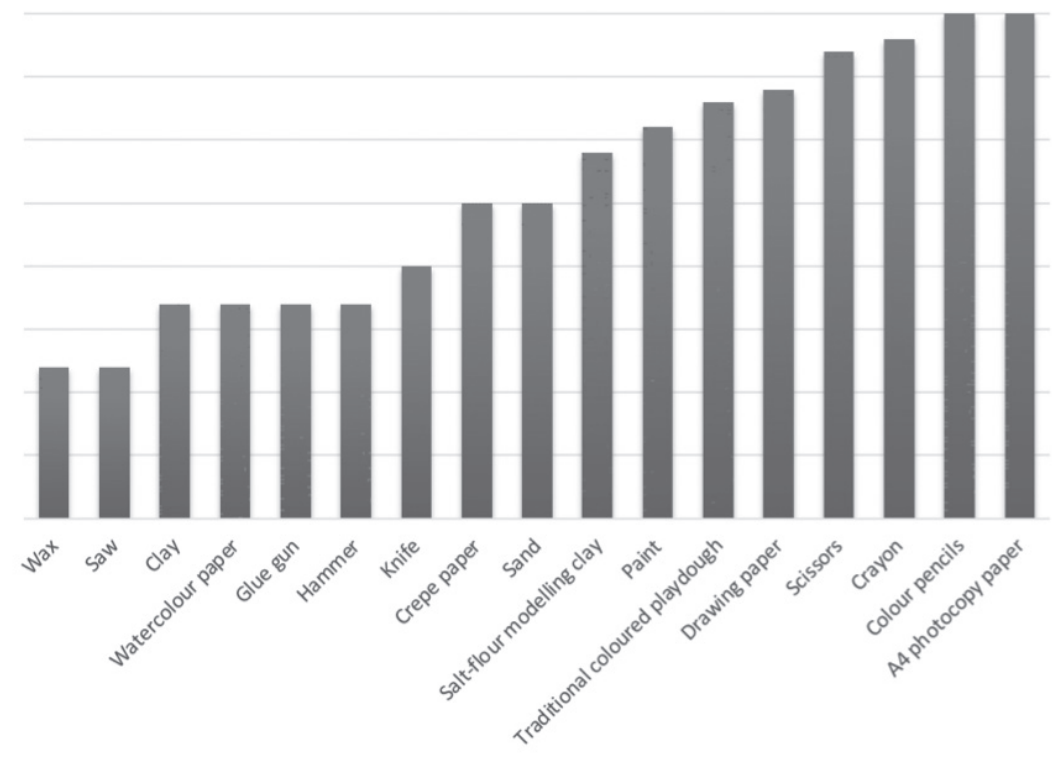

\section{Figure 3}

How the kindergartens judged the importance/frequency of the use of tools and materials on a five-point scale

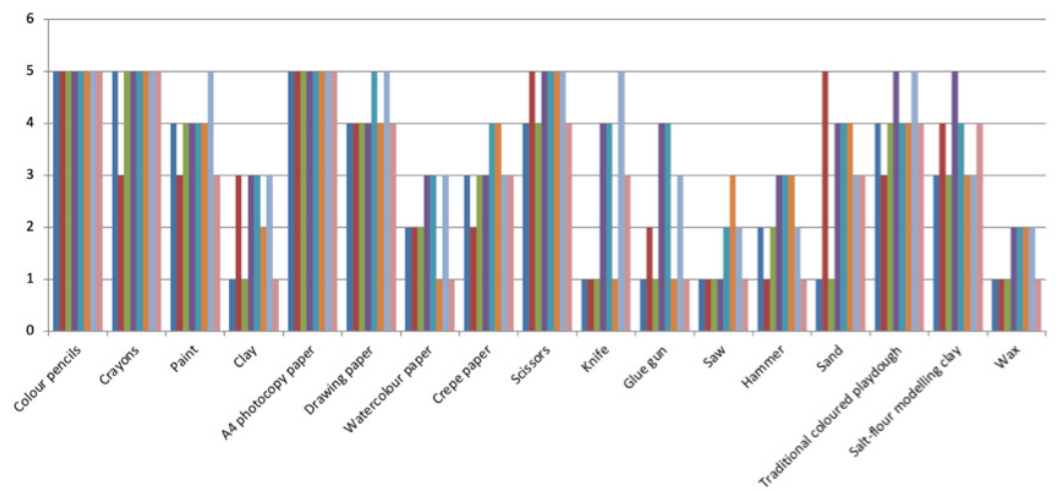

Generally, it can be stated that familiarity with the modelling materials (e.g., playdough, clay and wax) enables better results in the area of human figure depiction. The survey of the art materials available in each kindergarten 
and their relative importance made clear the predominance of $2 \mathrm{D}$ materials (see Figures 2, 3). We should not be surprised by the weakness of plastic skills, when kindergartens mostly offer only coloured pencils and A4 printing paper for the children to use.

This fact, already proven by the 2011 survey (Pataky, 2012) on the development of construction skills of children aged 6 to 12, was once again verified by the interviews and focus group discussions with preschool teachers involved in the current investigations: plastic artwork - object-making - is dangerous, messy and complicated. Fortunately, we have a reason to be optimistic, since, as can be seen here, this is not the case in every kindergarten.

\section{Figure 4}

Comparative model of drawing and modelling in 1974 and today

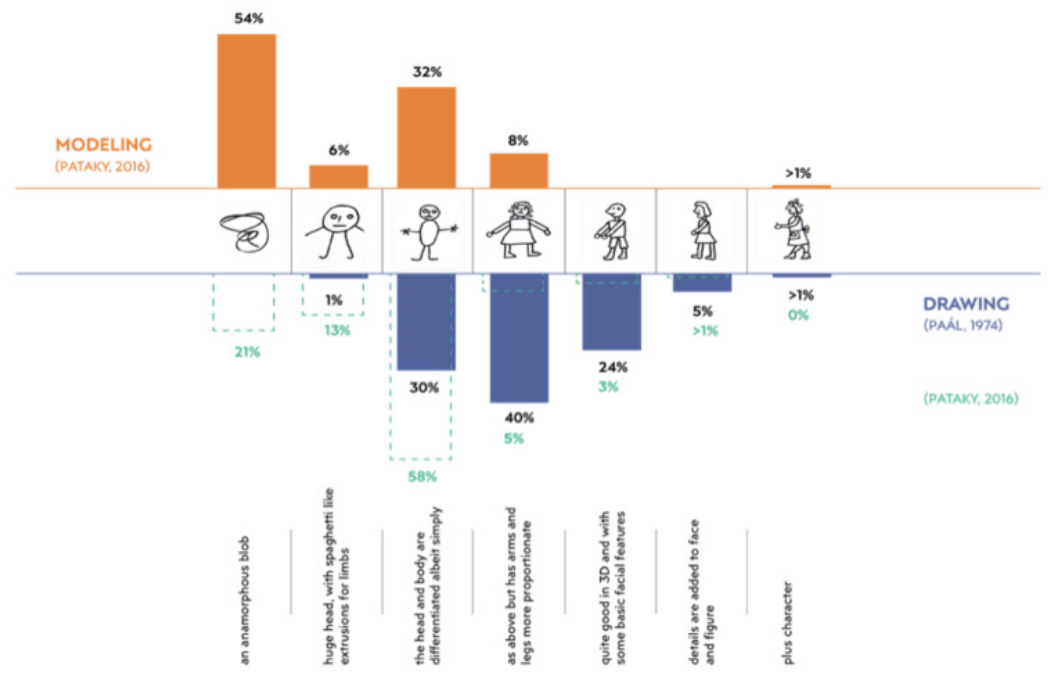

Taking the results of my research on both modelling $(3 \mathrm{D})$ and drawing (2D) together with Golomb's (1974) modelling and Paál's (1974) drawing results, it becomes clear that both modelling and drawing skills are less developed today than 40 years ago (Pataky, 2017a, 2017b) (Figure 4). ${ }^{10}$ In addition, children's plastic skills are even less developed today than their drawing skills. The reason for this phenomenon is rooted in the background variables, including the relative lack of $3 \mathrm{D}$ materials and emphasis (Figures 2,3 ). Plastic art skills are

10 Although my results represent conditions in Hungary, education inspection experts in the Netherlands expressed their concerns related to art education similarly in the report »Level artistic orientation 2015-2016 (Inspectorate of Education / Ministry of Culture and Science, 2017). 
delayed in comparison to drawing skills, and this development - just as in the case of drawing - is not linear. Plastic art representational skills 40 years ago developed parallel to the model of the development of drawing. In 2016, this does not seem to be the case.

\section{Figure 5}

Developmental model of plastic art skills in 2016

\section{DEVELOPMENT OF PLASTIC ART SKILLS BETWEEN 3-7 YEARS OF AGE}

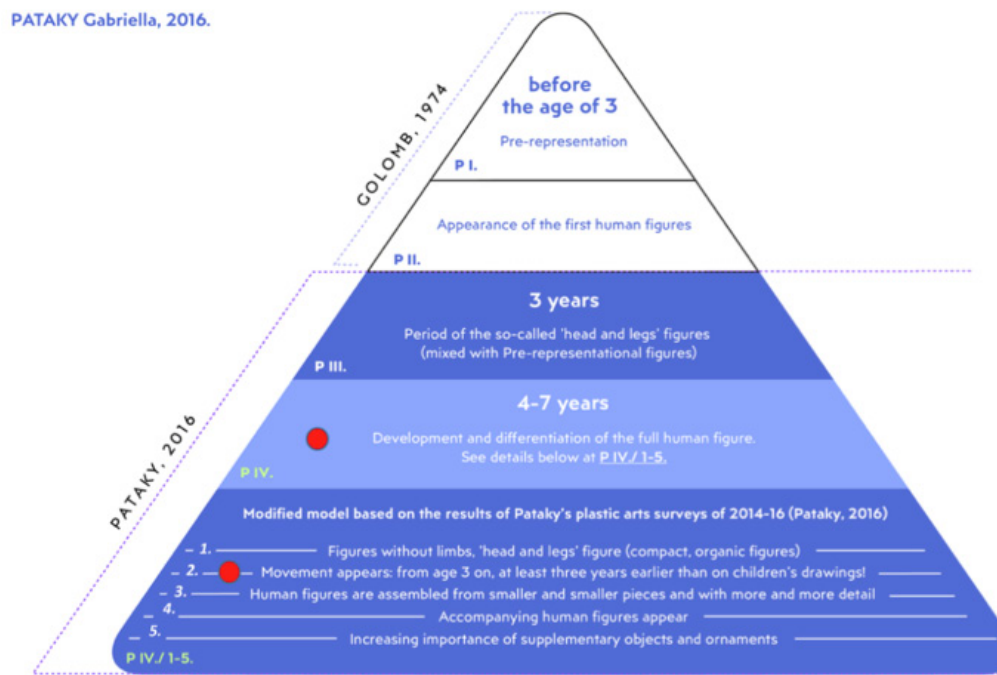

However, as shown under "Development and differentiation of the full human figure « in the model (Figure 5), the main and most promising difference in comparison to Golomb's (1974) results is in the early appearance of the representation of movement. This starts around age 3 in the case of plastic art figures created by children in my sample, at least three years before movement appears in their drawings. Although the figural aspect of the modelling was often difficult to recognise, the children's narration made clear their intent to represent action rather than static bodies. We constantly supplemented our participant observation with recording and analysis of the valuable narratives given by the children during the act of creation (that is, of the narration that accompanied the process of creation, and/or their commentaries on the work that they declared to be complete). 


\section{Children's creation in the art educational environment}

\section{Figure 6}

Where children like to create in the light of an iconographical study

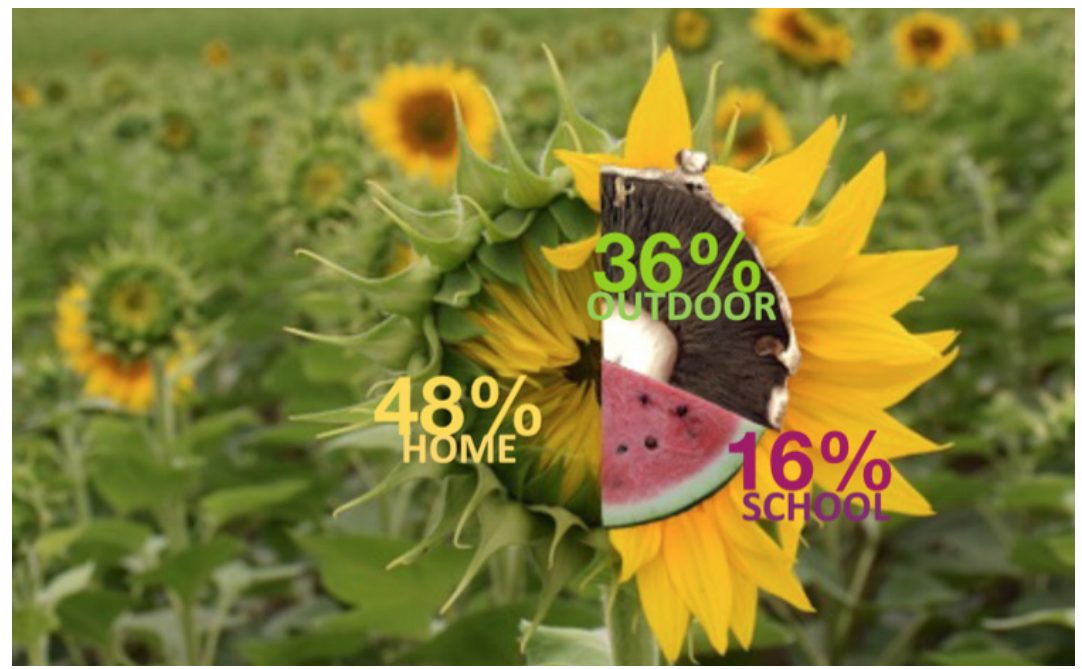

At this stage of the follow-on research (ongoing), the first impression of the observer is that the drawings are incredibly diverse in terms of drawn spaces and activities. Locations and activities appear on a wide spectrum. From this range, the locations can be narrowed down to three main categories (Figure 6). Some characteristic findings are:

- Surprisingly, a school environment only appears on a few drawings. When it does, a painful and closed environment, frontal teaching, and copying rather than creative approaches are emphasised.

- On most drawings, the environments are not even close to anything institutional.

- $\quad$ On many drawings, outdoor environments can be seen.

We preserved not only the drawings, but the accompanying narratives. Although many of the children commented on their drawings that creating is an activity they like pursuing together with those who love them - hence all of the grandmothers that appear - they do not think of creating as a social activity. The key finding: almost half of the children like to create amongst their family members, most of them at home. More than a third, $36 \%$, prefer to do so outside, while a mere $16 \%$ like to create at school! It would be fantastic if the children could find enjoyable, exciting creative spaces within institutional art education. These 
findings offer a clear message regarding what we, educators, should do: create enjoyable, exciting creative spaces within institutional art education.

\section{Discussion}

The research questions posed here asked how plastic, spatial $(3 \mathrm{D})$ creative capacities develop, and how they compare with the kindergarten's accustomed advancement of picture-creating, planar $(2 \mathrm{D})$ capabilities, and how kindergartners' skills as measured in the 1970s compare with those of kindergartners today. The follow-on project brought built environment education into the equation, asking what kinds of environments - where, and with whom - are most favourable to creation and arts education.

The research findings are summarised and visualised in the comparative model shown in Figure 4. The deterioration of children's drawing development from 1974 (Paál) until today is apparent, as well as deterioration from drawings in both studies (Generation Alpha and Generation X) to modelling today. A more promising result of comparing children's drawings and their plastic arts works, however, is the new pattern with respect to movement, with its depiction appearing much sooner in the case of plastic arts works than in drawings. The subject of our further research, currently already in progress, is the question of whether this observed result is due to the changed life conditions of the twenty-first century and the spread and character of entertainment practices aimed at children.

\section{Figure 7}

The complex development of visual literacy in early childhood

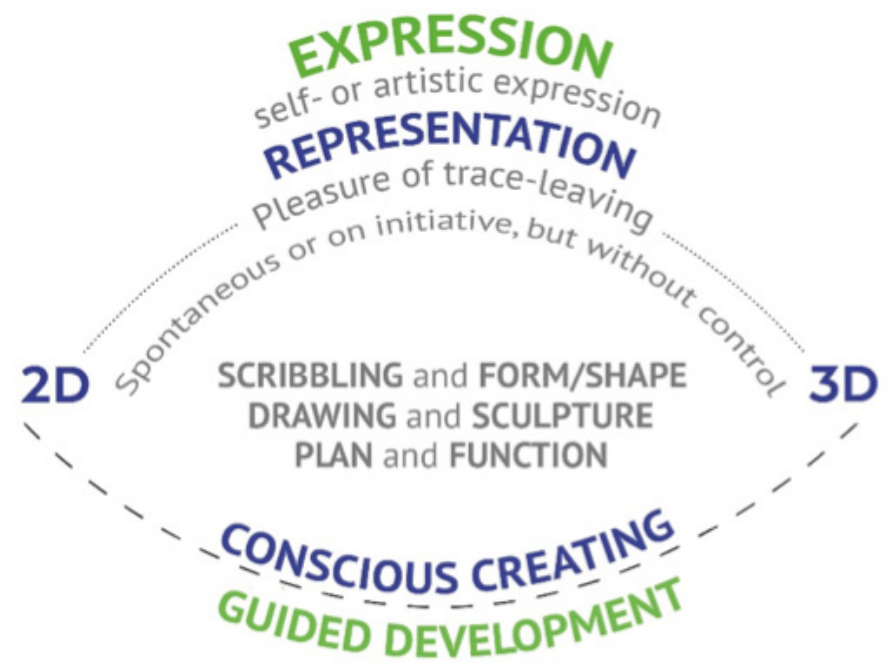


What is decisive is not the activity - drawing or modelling - but rather the medium, the material. Soft material in modelling makes it easily possible to change the form and give children a sense of achievement. When drawing, we leave enduring marks on the paper, choices that we cannot undo. Creations made from pliable materials are easily modified: the child is the immediate executor of the creative process and can alter it according to his or her wishes. This results not only in the pleasure of impact, but also the experience of success, a feeling of security and increased self-esteem (Figure 7).

Let us get back to the sentence: „Don't touch this or that! « What is the teacher's role in this? As well as being essential that the teacher offer the materials and tools, she or he must also initiate rather than direct. Instinctive adult examples develop analytical thinking, something that is anyway given far more emphasis than would be appropriate for this age group. Instead of templatebased activities focusing on the end product, our results point to the importance of sensory play activities and process-oriented creative activities as the desirable visual tasks in the preschool classroom.

The importance of sensory play is huge! Children should use clay, touch clay, collect experiences. What is needed is multifaceted development based on competence and rooted in real, lifelike situations. Moreover, it is not sufficient to initiate this just before school-entering age. Our activity system, aimed at fostering the complex development of visual literacy, goes beyond two-dimensional representation and the spontaneous, pleasurable trace-leaving of early childhood: it points the way to the development of multifaceted, balanced, competent personalities, focuses on expression rather than representation, and runs past imagery, across making forms in three-dimensions, through construction and modelling spaces, to the production of functional objects. The presence of this activity, based on a methodology reinforced by appropriate empirical research results, is essential to early childhood education.

In order to counteract the overemphasised presence of image-making exercises (Pataky, 2011), built environment culture is especially important in transdisciplinary visual and complex art education. The transdisciplinary aspect deserves more mention, as its competence range mixes elements of visual literacy with generally expected everyday skills development. A relevant example from the new branches of early childhood pedagogy is outdoor pedagogy, primarily on account of its competence set, effect mechanism and interaction with visual education.

Built environment education engages with the theory and practice of the deliverance of knowledge of the built environment, as well as with strengthening the connection between people and their own life-space. In contrast to passive observation, this kind of intervention inspires critical and analytical reception 
and the analysis of the various environmental stimuli. The proactive, creative perspective developed in this way contributes to the acquisition of the appropriate skills for the creation of common life-space. Education in the discipline of architecture has evolved, mirroring societal challenges and conditions. Built environment education can also be considered as a multitude of traditions with different national flavours.

Built environment education is becoming more and more important, not only in international pedagogy. This is illustrated by a government regulation created in Hungary in January 2015, which calls for the teaching of built environment and spatial culture from kindergarten to university. The basis of this regulation is the realisation that, on the one hand, knowledge about architecture and spatial culture improves visual skills and fundamental competencies needed in the twenty-first century, such as creativity and innovation, critical thinking, problem solving, decision making, civics, communication, cooperation and team work, self-understanding and self-regulation. On the other hand, as participation in urbanisation processes and in the shaping of the built environment comes to the fore, built environment competencies, such as spatial perception and the use and shaping of space, also become more prominent. Developing these competencies and teaching pupils about the built environment should be part of education from an early age, so that pupils develop a need for a quality environment and sensitivity towards aesthetic and social problems. As such, it is essential that the methodology of built environment education, the fundamental information and the educational opportunities present in the subject are made accessible to all participants in early childhood education.

\section{Conclusion}

One of the precursors of the research on educational spaces has a strong connection to the CEFR_VL prototype as well as to built environment education and young children's education. I am currently working on mapping basic elements of artistic and art educational environments, based on the CEFR_ VL. My new project is how to put CEFR_VL into practice in particular situations. ${ }^{11}$ As a result, a pedagogical innovation will be developed for teachers (decisionmakers, curricula developers) to detect whether an environment is suitable for a particular assignment/task/test/exercise/activity, and how it can be developed and improved effectively and sustainably.

Materials, equipment, tools and personal conditions will also be researched, the fortunate combination of which facilitates the optimum

11 See http://envil.eu/the-benefits-of-the-nvil-situation-wheel/. 
development of visual competencies. The system forms the basis of computer software that is now in the phase of development and testing, which will help schools and teachers to identify what needs to be done in order to optimise conditions or gain reinforcement if these conditions are already optimal. Serving the purpose of both evaluation and optimisation, the program (application) also hopes to provide teachers working under more difficult circumstances with reliable feedback on areas of performance that are not affected by material conditions. Teachers will find information and encouragement to improve the efficient use of resources available for development by devoting them to a well-defined group of conditions. In South Korea, we have already introduced the research design and the measurement tools with the first results of a currently ongoing pilot survey (Pataky \& Rekvényi, 2017). We are in the process of formulating collaboration on common research projects with several partner universities with teacher training programmes. We want to explore whether our experiences in Hungary are characteristic of the rest of Europe, and what similarities and differences can be determined for the rest of the world. Under the auspices of the InSEA organisation, we are now in contract discussions with several programmes in the Asian section (Japan and China).

Possible obstacles are that there are no or very few references that we can use for guidance, and those that do exist do not share our orientation. It is very invisible territory, because those who are not versed in children's plastic creation and its assessment will not see anything in what they do. There are major material challenges: although the materials are cheap, a great deal of expertise is required from those who are familiar with the area and know how to work with the materials, in order for them to be used effectively. Productive research requires participant observation, which is very work- and energy-intensive.

At this point, it is worth recalling the directions in early childhood visual education that are relevant here:

The goals of the development of visual competences and its elements were defined for us by the CEFR_VL. Some specific elements of the prototype, such as experimentation, are extremely important for the very young. We have to take the skills that we are born with and that may be dormant and bring them back to life, making them vibrantly alive again with appropriate motivation, that is, exercises. In everyday practice, as well as in the research field, it is equally important that these exercises work incorporated into situations relevant to children's everyday lives, using the toolset of contemporary visual art. As with all developments and improvements, they have to be calibrated to children's age particularities. Knowing our options, as age and development progresses, these 
calibrations need to be adaptive, tailored to the individual and made with more and more challenges. Special forms of assessment, the example or narrative, as well as other kinds of formative assessment in early childhood, can be definitive in terms of the long-term fostering of creativity. Educational-psychological research in connection with built environment research shows just how large an effect environment and institutional infrastructure has on the development of children.

Based on the data drawn from children's drawings, it becomes clear just how important it is to view visual development in early childhood with criticism and self-criticism. The competence development of visual literacy, as one of the most important transversal competencies, needs a paradigm shift. This is what enthusiastic art educators are working on worldwide, together with InSEA; we welcome all colleagues who wish to join us in this quest.

How, then, is the optimal and supportive educational space created in the digital era? What could be a truly inspiring environment for art education? How should a studio be best set up in the twenty-first century? Is there a reason for the clean desk policy (CDP) to be present in schools?

To summarise the results of this research at the current stage, which has been undertaken together with artists, teacher training students and children: the attitude and desire is the same in all three groups; creating and selfexpression are such natural activities and strong drives that we can confidently say that creative spaces are not location-specific, but personal. Creation takes place wherever the creator is or where they like to be. If we want to improve institutional art education, we have to work on school creative spaces becoming creative person-focused. We have to make art classes and art education into an adventure; both teaching and learning will then be effective in the art room.

We have a clear message from children as to what we should do: help to create enjoyable, exciting creative spaces within institutional art education. Based on all of the outcomes presented here, it is clear that we have to reinvent art education: the conditions of art education are not optimal or supportive enough!

\section{Acknowledgment}

I would like to thank all of the children and teachers who participated in the study, and Csaba Csíkos for his help with statistics. The statistical analysis of our findings is ongoing, and we hope to publish more detailed results in the near future. 


\section{References}

Bodóczky, I. (2000). Az értékelés problémái a vizuális nevelésben [The problems of assessment in visual education]. Iskolakultúra, 10(6-7), 15.

Bodóczky, I. (2003). Vizuális nevelés [Visual education]. Magyar Iparművészeti Egyetem.

Bodor, P. (Ed.) (2013). Szavak, képek, jelentés. Kvalitatív kutatási olvasókönyv [Words, pictures, meaning: Qualitative research reader]. L'Harmattan.

Golomb, C. (1974). Young children's sculpture and drawing - A study in representational development. Harvard University Press.

Guba, A., Pataky, G., \& Tóth, E. (2017). Épített környezeti nevelés az óvodában [Built environment education in the kindergarten]. Magyar Építész Kamara, kultúrAktív.

Inspectorate of Education / Ministry of Culture and Science [Inspectie van het Onderwijs / Ministerie van Cultuur en Wetenschap]. (2017). Rapport Peil. Kunstzinnige oriëntatie 2015-2016 [The Peil Report. Artistic orientation 2015-2016]. https://www.onderwijsinspectie.nl/documenten/rapporten/2017/03/27/ rapport-kunstzinnige-orientatie

Kárpáti, A., \& Pataky, G. (2016). A közös európai vizuális műveltség referenciakeret [The European framework of reference for visual literacy]. A Neveléstudomány folyóirat, Új perspektívák a müvészetpedagógiában, 1, 6-21. http://nevelestudomany.elte.hu/index.php/2016/o4/a-kozos-europaivizualis-muveltseg-referenciakeret/

Katona, F. (2001). »Az öntudat újraébredése« A humán idegrendszer ontogenesise [»The reawakening of consciousness «: The ontogenesis of the human nervous system]. Medicina Könyvkiadó. Kirchner, C., \& Kirschenmann, J. (2015). Kunst unterrichten. Didaktische Grundlagen und schülerorientierte Vermittlung [Teaching art: Didactic foundations and pupil-oriented mediation].

Friedrich Verlag.

Lakatos, B. M. (2007). »Kör, kör, ki játszik«. Mire tanitanak a népi játékok? [»Circle, circle, who is playing?« What do folk games teach us?]. In I. Bollókné Panyik (Ed.), Gyermek-, Nevelés-, Pedagógusképzés (pp. 103-116). Trezor Kiadó. http://vmek.oszk.hu/o910o/o9191/o9191.pdf Mitchell, W. J. T. (1994). Picture theory: Essays on verbal and visual representation. University of Chicago Press.

Mitchell, W. J. T. (2004). What do pictures want? The lives and loves of images. University of Chicago Press. OECD. (2005). The definition and selection of key competencies. Executive summary. www.oecd. org/ edu/statistics/deseco-OLSAT

Paál, Á. (1970). A gyermekrajzok fejlődésének motivációi [The motivations for the development of children's drawings]. Magyar Pszichológiai Szemle, 27(4), 373-378.

Pataky, G. (2011). Object making and design in the visual education of children aged 6-12 in the light of a diagnostic survey. In A. Kárpáti \& E. Gaul (Eds.), InSEA World Congress (pp. 182-193). HATA. Pataky, G. (2012). Vizuális képességek fejlödése 6-12 éves korban, a tárgykultúra tanitásának területén [The development of visual skills at the age of 6-12 years in the field of teaching object making]. ELTE TÓK. Pataky, G. (2016). Nutzung des Kompetenzstrukturmodells in der Forschung - Dokumentation eines 
Vorhabens in Ungarn [The use of the competence structure model in the research - Documentation of a project in Hungary]. In E. Wagner \& D. Schönau (Eds.), Cadre Europ.en Commun de Référence pour la Visual Literacy (pp. 372-379). Waxmann.

Pataky, G. (2017a). Plasztikai képességek fejlődése 3-7 éves korban a CEFR_VL kompetenciamodell tükrében. Diagnosztikus vizsgálat a síkbeli $(2 D)$ és a térbeli $(3 D)$ alkotások köréböl a vizuális nevelés rendszerében [Plastic skills development from age 3 to 7 years in the mirror of the CEFR_VL

Competence Model. Diagnostic study of $2 \mathrm{D}$ and $3 \mathrm{D}$ creations within the structure of visual education]. Gyermeknevelés, 5(1), 171-187. http://old.tok.elte.hu/gyermekneveles/17_1_szam/pub/pataky.pdf Pataky, G. (2017b). Nicht anfassen! Veränderung der zeichnerischen und plastischen Fähigkeiten von Kinder im Vergleich von heute mit 1974 [Hands off! Changes in drawing and plastic skills of today's children in comparison with the ones in 1974]. Werkspuren 2. https://werkspuren.ch/

Pataky, G., \& Rekvényi, V. (2017). How is the optimal art education space created in the digital era? Art education research in the light of teacher training students' critical views in two European countries (Hungary and Scotland). $35^{\text {th }}$ InSEA World Congress, Daegu, Korea. http://www.insea2017.org/ download/InSEA2017_ProgramBooK.pdf

Reulecke, W., \& Rollett, B. (1976). Pädagogische Diagnostik und lernzielorientiertes Tests [Pedagogical diagnostics and learning goal-oriented tests]. In K. Pawlik (Ed.), Diagnose und Diagnostik (pp. 179-185). Klett.

Szőkéné Halász, É. (2010). Pszichológiai és pedagógiai ismeretek [Psychological and pedagogical knowledge]. http:/www.humantiszk.hu/modularis_jegyzetek/6_1_szokene.pdf

Tóth, E., \& Pataky, G. (2019). Why architecture and the built environment matters in art education. In M. Kallio-Tavin \& O. Sushchenko (Eds.), Scientific and Social interventions in art education 2 (pp. 29-35). Special Issue of InSEA Congress 2018. https://wiki.aalto.fi/pages/viewpage.action?pageId=148283892 Wagner, E., \& Schönau, D. (Eds.) (2016). Cadre Europen Commun de Référence pour la Visual Literacy - Prototype.

\section{Biographical note}

Gabriella Pataky, PhD, is an associate professor at Eötvös Loránd University, Faculty of Primary and Pre-School Education (ELTE TÓK), head of Department of Visual Education and 3612+VisualSkillsLab in Budapest/Hungary, where she is responsible here for the art teacher training program.

Her main research fields are visual culture, visual literacy, alternative methods and contemporary art in visual education, multicultural education, transdisciplinary art education, built environment, development of plastic skills. She is one of the elected European world councilors at the InSEA World Council and one of the board members of the European Network for Visual Literacy (ENViL). 